NASA/TM-2000-209891, Vol. 163

T. $-\infty$

i

Technical Report Series on the Boreal Ecosystem-Atmosphere Study (BOREAS)

Forrest G. Hall and Andrea Papagno, Editors

\title{
Volume 163
}

BOREAS TE-10 Photosynthetic Response Data

Elizabeth Middleton, NASA Goddard Space Flight Center,

Greenbelt, Maryland

Joseph Sullivan, University of Maryland, College Park

National Aeronautics and

Space Administration

Goddard Space Flight Center

Greenbelt, Maryland 20771

October 2000 
Available from:

NASA Center for AeroSpace Information 7121 Standard Drive

Hanover, MD 21076-1320

Price Code: A17
National Technical Information Service 5285 Port Royal Road

Springfield, VA 22161

Price Code: A10 


\title{
BOREAS TE-10 Photosynthetic Response Data
}

\author{
Elizabeth M. Middleton, Joe H. Sullivan
}

\section{Summary}

The BOREAS TE-10 team collected several data sets in support of its efforts to characterize and interpret information on the gas exchange, reflectance, transmittance, chlorophyll content, carbon content, hydrogen content, nitrogen content, and photosynthetic response of boreal vegetation. This data set contains measurements of quantitative parameters and leaf photosynthetic response to increases in light conducted in the SSA during the growing seasons of 1994 and 1996 using an oxygen electrode system. Leaf photosynthetic responses were not collected in 1996. The data are stored in tabular ASCII files.

\section{Table of Contents}

1) Data Set Overview

2) Investigator(s)

3) Theory of Measurements

4) Equipment

5) Data Acquisition Methods

6) Observations

7) Data Description

8) Data Organization

9) Data Manipulations

10) Errors

11) Notes

12) Application of the Data Set

13) Future Modifications and Plans

14) Software

15) Data Access

16) Output Products and Availability

17) References

18) Glossary of Terms

19) List of Acronyms

20) Document Information

\section{Data Set Overview}

\subsection{Data Set Identification \\ BOREAS TE-10 Photo Response Data}

\subsection{Data Set Introduction}

This data set describes the relationship between sample location, sample age, oxygen evolution measurements, and quantitative parameters in the canopies of the BOReal Ecosystem-Atmosphere Study (BOREAS) Southern Study Area (SSA) Old Black Spruce (OBS), Old Jack Pine (OJP), Young Jack Pine (YJP), Old Aspen (OA), Old Aspen-Auxiliary (OA-AUX), Young Aspen (YA), and Young Aspen-Auxiliary (YA-AUX) sites during the growing seasons of 1994 and 1996. This data set was collected and prepared to provide information on the oxygen evolution measurements and quantitative parameters of OBS (Picea mariana), OJP (Pinus banksiana and Apocynum androsaemifolium), YJP (Pinus banksiana), YA (Populus tremuloides and Corylus cornuta Marsh) OA (Populus tremuloides and Corylus cornuta Marsh), YA-AUX (Populus tremuloides, Corylus cornuta Marsh, and Picea 
glauca), and OA-AUX (Populus tremuloides and Corylus cornuta Marsh). This information will be useful for assessing photosynthetic differences between different species, age classes, and canopy layers in the boreal forest.

\subsection{Objective/Purpose}

The purposes of the work were to:

- Obtain a canopy profile of leaf/needle growth measurements and oxygen evolution rates during photosynthesis.

- Examine interspecific and interseasonal differences in these parameters.

- Relate these differences to the photosynthetic measurements taken in the field.

\subsection{Summary of Parameters}

The photo response data record includes the date when the measurements were taken, quantitative parameters (color of top of leaf, color of bottom of leaf, needle count per sample, mean leaf/needle length of three needles per age class or three measurements of the same leaf, mean leaf/needle width of three needles per age class or three measurements of the same leaf, mean leaf/needle thickness of three needles per age class or three measurements of the same leaf, length/width ratio, mean hemisurface area of three needles per age class or three measurements of the same leaf, dry and fresh weights of leaf/petiole/needle, dry and fresh weights of leaf/petiole/needle/stem, fresh specific leaf weight, dry specific leaf weight, percent water content for the whole shoot including stem, percent water in the sample without stem), and oxygen evolution (maximum assimilation-Amax, dark respiration-darkresp, and stomatal limitation-stomlim).

\subsection{Discussion}

Samples were taken from seven forest sites in the SSA: OBS, OJP, YJP, YA-AUX, YA, OA-AUX, and OA during each of the three Intensive Field Campaigns (IFCs) in 1994 and the growing season of 1996. Measurements were taken in the laboratory. Quantitative measurements such as length, width, thickness, color, needle count/age class, and fresh weight were examined in an effort to characterize photosynthetic differences. An oxygen electrode system (Hansatech Corporation, Kingslynn, England), which measures the rate of oxygen evolution during photosynthesis, was used for photosynthesis measurements under controlled light and temperature and with saturating concentrations of carbon dioxide $\left(\mathrm{CO}_{2}\right)\left(5,10 \%\right.$ in air), which overcome stomatal resistances to $\mathrm{CO}_{2}$ uptake. This information will be useful in examining differences in photosynthetic capacity between species and within canopies of the boreal forest. Measurements were taken in the laboratory.

\subsection{Related Data Sets}

BOREAS TE-10 Leaf Chlorophyll

BOREAS TE-10 Leaf Optical Properties

\section{Investigator(s)}

\subsection{Investigator(s) Name and Title}

Dr. Elizabeth Middleton Project Scientist

Dr. Joseph Sullivan Assistant Professor

\subsection{Title of Investigation}

$\mathrm{CO}_{2}$ and Water Fluxes in the Boreal Forest Overstory: Relationship to fAPAR and Vegetation Indices for Needles/Leaves 


\subsection{Contact Information}

\section{Contact 1:}

Elizabeth M. Middleton, Ph.D.

Biospheric Sciences Branch, Code 923

NASA GSFC

Greenbelt, MD 20771

(301) 286-8344

(301) 286-0239 (fax)

betsym@ltpsun.gsfc.nasa.gov

\section{Contact 2:}

Joe H. Sullivan, Ph.D.

Department of Natural Resource Sciences and Landscape Architecture

University of Maryland

College Park, MD 20742

(301) 405-1626

(301) 314-9308 (fax)

botn9@umdd.umd.edu

\section{Contact 3:}

Andrea Papagno

Raytheon ITSS

Code 923

NASA GSFC

Greenbelt, MD 20771

(301) 286-3134

(301) 286-2039 (fax)

Andrea.Papagno.gsfc.nasa.gov

\section{Contact 4:}

Shelaine Curd

Raytheon ITSS

Code 923

NASA GSFC

Greenbelt, MD 20771

(301) 286-2447

(301) 286-2039 (fax)

Shelaine.Curd@gsfc.nasa.gov

\section{Theory of Measurements}

An oxygen electrode system (Hansatech Corporation, Kingslynn, England), which measures the rate of oxygen evolution during photosynthesis, was used for photosynthesis measurements under controlled light and temperature and with saturating concentrations of $\mathrm{CO}_{2}(5,10 \%$ in air $)$, which overcome stomatal resistances to $\mathrm{CO}_{2}$ uptake. Single-leaf measurements were made using cut leaf disks having areas of $2.27 \mathrm{~cm}^{2}$ of aspen, hazelnut, and dogbane. For full illumination by the light source, enough material was needed to fill the electrode system chamber without any overlap; thus, multiple needle samples were used to measure the coniferous species. Five needles within the same sample id and the same age class were used to measure jack pine; 15 to 20 needles within the sample id and the same needle age class were used to measure black spruce. Saturating photosynthetic photon flux density (PPFD) $\left(2175 \mu \mathrm{mol} / \mathrm{m}^{2} / \mathrm{s}\right)$ was supplied by a Bjorkman lamp connected to a Hansatech 
LS-2 light source. Estimates of dark respiration (darkresp) were made after incremental light reductions (implemented for light response curves, Middleton et al. [1997] and Sullivan et al. [1996]) and acclimation to zero illumination.

Stomatal limitation is calculated using the standard equation from Farquhar and Sharkey (1982):

$$
\text { stomatal limitation }=\left(\left(a_{\max }-A\right) / a_{\max }\right) \times 100
$$

Terrestrial Ecology (TE)-10 used maximum assimilation without stomatal limitations $\left(a_{\max }\right)$ from the light-saturated and $\mathrm{CO}_{2}$-saturated $\mathrm{O}_{2}$ measurements as an estimate of " $\mathrm{a}_{\max }$," and light-saturated maximum assimilation with stomatal limitations (A) from field measurements using an Infrared Gas Analyzer (IRGA) System. Amax from $\mathrm{O}_{2}$ is without a stomatal effect because of the high $\mathrm{CO}_{2}$ gradient overcoming any stomatal barrier to diffusion. $\mathrm{A}$ in the field does potentially include some other limitations in addition to stomatal closure (e.g., biochemical), but that possibility was ignored. This is an accepted way to estimate how much influence the stomates are having on gas exchange.

\section{Equipment}

\subsection{Sensor/Instrument Description}

\subsubsection{Collection Environment}

The vertical profile of the canopy was divided into three layers: top, middle, and bottom. One layer of white spruce at YA-AUX was measured during IFC-2 only. At OJP, the understory species dogbane (Apocynum androsaemifolium) was measured during IFC-2. At OA and YA, there was a hazelnut (Corylus cornuta Marsh) understory that was measured during each IFC.

Gas exchange measurements and sample collections were made from platform canopy access towers constructed onsite by the BOREAS staff at the OBS, OJP, OA, and OA-AUX sites and from the ground at the YA, YA-AUX, and YJP sites. In 1994, data were obtained during three discrete measurement periods ( 1 to 2 measurement days each period) designated by BOREAS as IFC-1, -2 , or -3 . These IFCs were selected to measure parameters at bud breaks and leaf expansion (24-May-1994 to 12-Jun-1994), midsummer or peak growing season (26-Jul-1994 to 08-Aug-1994), and the onset of dormancy and senescence in autumn (30-Aug-1994 to 15-Sep-1994). In 1996, data were obtained during three discrete measurement periods ( 1 to 2 measurement days each period) designated as the spring, summer, and fall seasons. These seasons were selected to measure parameters at bud breaks and leaf expansion (21-April-1996 to 24-June-1996), midsummer or peak growing season (10-July-1996 to 17-July-1996), and the onset of dormancy and senescence in autumn (20-Oct-1996 to 31-Oct-1996).

Measurements were collected from both the upper and lower canopy sections of the trees adjacent to the canopy access towers at the OJP, OBS, OA, and OA-AUX sites and on the young trees present near the flux tower sites at the YJP, YA, and YA-AUX sites. For Pinus banksiana, measurements were made on each needle class present. For Picea glauca, age classes 1 (1994) and 2 (1993) were measured during IFCs- 2 and -3 . For Picea mariana, the newest age was measured alone, while needles 2 and 3 years were combined in one measurement, as were 4- and 5-year-old needles. Broadleafs were measured as individual leaves with their petioles attached. At least eight replicate measurements and sample collection per IFC, canopy location, and age group were made for each species. These activities took place on trees that were accessible from the canopy access towers (approximately four trees, with two upper and lower branches measured per tree) at the OBS, OJP, OA, and OA-AUX sites and on the same number of trees each IFC at the YJP, YA, and YA-AUX sites.

Samples were sealed in plastic bags with moist towels and placed on ice for transport to the laboratory for further analysis. The laboratory was provided by BOREAS staff in Paddockwood, SK, approximately $60 \mathrm{~km}$ from the research sites. Each sample was divided into two components with one portion used for measurement of oxygen evolution and chlorophyll extraction and the remaining material used for analysis of leaf optical properties and carbon-hydrogen-nitrogen content. 
At the laboratory, samples were stored in the dark in the refrigerator until they were measured. Laboratory measurements included quantitative properties, optical properties, and oxygen evolution. Quantitative parameters included the color of top of the leaf, the color of the bottom of the leaf, needle count per sample, mean leaf/needle length of three needles per age class or three measurements of the same leaf, mean leaf/needle width of three needles per age class or three measurements of the same leaf, mean leaf/needle thickness of three needles per age class or three measurements of the same leaf, length/width ratio, mean hemisurface area of three needles per age class or three measurements of the same leaf, dry and fresh weights of leaf/petiole/needle, and dry and fresh weights of leaf/petiole/needle/stem. A foliar disk sample of $2.27 \mathrm{~cm}^{2}$ diameter was taken from each of the broadleaf samples for oxygen evolution. A mass of needles, 5 for jack pine and 15 to 20 for black spruce, chopped, was taken from the conifers for oxygen evolution. The foliar disk samples and chopped needles were dried and weighed following the extraction of their photosynthetic pigments.

The rest of the samples were dried in an oven at $70^{\circ} \mathrm{F}$ for 3 days, and their dry weights were recorded. The oxygen evolution samples were of a known weight.

\subsubsection{Source/Platform}

Samples were taken from towers except at YJP, YA-AUX, and YA, and were cut using knives.

\subsubsection{Source/Platform Mission Objectives}

Not applicable.

\subsubsection{Key Variables}

Oxygen evolution (maximum assimilation-Amax, dark respiration-darkresp, stomatal limitation-stomlim).

Quantitative parameters (color of top of leaf, color of bottom of leaf, needle count per sample, mean leaf/needle length of three needles per age class or three measurements of the same leaf, mean leaf/needle width of three needles per age class or three measurements of the same leaf, mean leaf/needle thickness of three needles per age class or three measurements of the same leaf, length/width ratio, mean hemisurface area of three needles per age class or three measurements of the same leaf, dry and fresh weights of leaf/petiole/needle, dry and fresh weights of leaf/petiole/needle/stem, fresh specific leaf weight, dry specific leaf weight, percent water content for the whole shoot including stem, and percent water in the sample without stem).

\subsubsection{Principles of Operation}

Maximum assimilation and dark respiration were obtained from the rates of oxygen evolution. An oxygen electrode system (Hansatech Corporation, Kingslynn, England), which measures the rate of oxygen evolution during photosynthesis, was used for photosynthesis measurements under controlled light and temperature and with saturating concentrations of $\mathrm{CO}_{2}(5,10 \%$ in air $)$, which overcome stomatal resistances to $\mathrm{CO}_{2}$ uptake. Single-leaf measurements were made using cut leaf disks having areas of $2.27 \mathrm{~cm}^{2}$ of aspen, hazelnut, and dogbane. For full illumination by the light sources enough material was needed to fill the electrode system chamber without any overlap; thus, multiple needle samples were used to measure the coniferous species. Five needles within the same sample id and the same age class were used to measure jack pine; 15 to 20 needles within the sample id and the same needle age class were used to measure black spruce. Stomatal limitation was calculated using the standard equation from Farquhar and Sharkey (1982). Quantitative measurements enabled TE-10 to measure the percent water content and to obtain leaf/needle dimensions.

\subsubsection{Sensor/Instrument Geometry}

All instrumentation took place under laboratory conditions. 


\subsubsection{Manufacturer of Sensor/Instrument}

Circulating Water Bath Set

Lauda, Model RM20B

Fisher Scientific

585 Alpha Drive

Pittsburgh, PA 15238

$1(800) 766-7000$

LED Light Source

Hansatech Model LH36 Ultralight

Hansatech Corporation

Kingslynn, UK

LI-COR Area Meter

Model Number 3100

LI-COR, Inc.

4421 Superior Street

P.O. Box 4425

Lincoln, NE 68504-0425

USA

(402) 467-3576

(402) 467-2819 (fax)

Oxygen Electrode

Hansatech Corporation

Kingslynn, UK

\subsection{Calibration}

\subsubsection{Specifications}

The weighing balance was accurate to $0.01 \mathrm{~g}$. The analytical balance was accurate to $0.0001 \mathrm{~g}$. The leaf area meter was accurate to within $1.00 \%$.

\subsubsection{Tolerance}

No tolerance level was set.

\subsubsection{Frequency of Calibration}

The oxygen evolution system was calibrated using $\mathrm{O}_{2}(1 \mathrm{cc}$ air) injected into the system before each sample run. The leaf area meter was calibrated before each use with a $10-\mathrm{cm}$ disk. Measurements of weight (mass) were reset to zero before each sample reading.

\subsubsection{Other Calibration Information \\ None.}

\section{Data Acquisition Methods}

On the towers at OA, OA-AUX, OBS, YJP, and OJP, top samples were taken from the top tower level, middle samples from the middle level, and bottom samples from the bottom tower level. At YA and YA-AUX, top samples were taken from the upper third, middle samples from the middle third, and bottom samples from the lower third part of the trees. At YA-AUX, only a top layer of the white spruce (Picea glauca) canopy was sampled. At OJP, there was a dogbane (Apocynum androsaemifolium) understory during IFC-2. At OA and YA, there was a hazelnut (Corylus cornuta Marsh) understory. Stem and leaf samples were harvested from each layer and immediately placed 
within a plastic bag that also contained a moist towel. For transport to the laboratory, the bags were placed in a cooler. For black spruce, age classes 1,2, and 3 were separated from ages 4 and 5 , until analysis was performed at the laboratory. For jack pine, age classes 1,2, and 3 were separated in the field before being brought to the laboratory. For white spruce, age class 1 was separated from age classes 2 and 3, which were separated from 4 and 5. Petioles were kept on all the broadleaves. At the laboratory, samples were stored in the dark in the refrigerator until they were measured.

Laboratory measurements included quantitative properties, optical properties, and oxygen evolution. Quantitative measurements that were performed on each sample age class included fresh weight using a balance; mean leaf (hemi-surface) area using a leaf area meter; mean length, mean width, and mean thickness of leaf/needles and conifer stems using a ruler and calipers; color of top (adaxial) and bottom (abaxial) using Munsell Color Charts (Munsell Color (Firm), 1977); and needle count/age class. An oxygen electrode system (Hansatech Corporation, Kingslynn, England), which measures the rate of oxygen evolution during photosynthesis, was used for photosynthesis measurements under controlled light and temperature and with saturating concentrations of $\mathrm{CO}_{2}(5$, $10 \%$ in air), which overcome stomatal resistances to $\mathrm{CO}_{2}$ uptake. Measurements were made on leaf discs or needle subsets. Single-leaf measurements were made using cut leaf disks having areas of 2.27 $\mathrm{cm}^{2}$ of aspen, hazelnut, and dogbane. For full illumination by the light source, enough material was needed to fill the electrode system chamber without any overlap; thus, multiple needle samples were used to measure the coniferous species. Five needles within the same sample id and the same age class were used to measure jack pine; 15 to 20 needles within the sample id and the same needle age class were used to measure black spruce. The electrode was maintained at a constant temperature using a circulating water bath (Lauda, Model RM20B), reset to approximately maximum daytime air temperature per IFC $\left(26^{\circ} \mathrm{C}\right.$ in IFC- 1 and $-3,28^{\circ} \mathrm{C}$ in IFC-2). Photosynthesis capacity (light-saturated photosynthesis) or Amax was determined within 2 to 24 hours after the field measurements. Saturating PPFD $\left(2175 \mu \mathrm{mol} / \mathrm{m}^{2} / \mathrm{s}\right)$ was supplied by a Bjorkman lamp connected to a Hansatech LS-2 light source. Estimates of dark respiration (darkresp) were made after incremental light reductions (implemented for light response curves, Middleton et al. [1997] and Sullivan et al. [1996]) and acclimation to zero illumination.

\title{
6. Observations
}

\author{
6.1 Data Notes \\ None.

\subsection{Field Notes \\ None.}

\section{Data Description}

\subsection{Spatial Characteristics}

\subsubsection{Spatial Coverage}

At the SSA OJP, YJP, OBS, OA, and OA-AUX tower sites, branch samples were taken from trees within reach from all sides of the towers. There were no towers at the other sites. At each site, at least five trees had the required layers for that site were sampled. The SSA measurement sites and associated North American Datum of 1983 (NAD83) coordinates are:

- SSA-OA canopy access tower located $100 \mathrm{~m}$ up the path to the flux tower site, site id C3B7T, Lat/Long: $53.62889^{\circ} \mathrm{N}, 106.19779^{\circ} \mathrm{W}$, Universal Transverse Mercator (UTM) Zone 13 , $\mathrm{N}: 5,942,899.9 \mathrm{E}: 420,790.5$. 
- $\quad$ SSA-OA-AUX canopy access tower located by the trailhead/parking area for the path leading to the flux tower at site id C3B7T, Lat/Long: $53.62889^{\circ} \mathrm{N}, 106.19779^{\circ} \mathrm{W}, \mathrm{UTM}$ Zone 13 , $\mathrm{N}: 5,942,899.9 \mathrm{E}: 420,790.5$. This OA-AUX site was farther up the path than SSA-OA from the flux tower site.

- $\quad$ SSA-OBS canopy access tower located at the flux tower site, site id G8I4T, Lat/Long: $53.98717^{\circ} \mathrm{N}, 105.11779^{\circ} \mathrm{W}$, UTM Zone $13, \mathrm{~N}: 5,982,100.5 \mathrm{E} ; 492,276.5$.

- $\quad$ SSA-OJP canopy access tower flux tower site, site id G2L3T, Lat/Long: $53.91634^{\circ} \mathrm{N}$, $104.69203^{\circ} \mathrm{W}$, UTM Zone 13, N:5,974,257.5 E:520,227.7.

- $\quad$ SSA-YA canopy access tower, site id D0H4T, Lat/Long: $53.65601^{\circ} \mathrm{N}, 105.32314^{\circ} \mathrm{W}, \mathrm{UTM}$ Zone 13, N:5,945,298.9, E:478,644.1.

- $\quad$ SSA-YA-AUX, site id D6H4A, Lat/Long: $53.708^{\circ} \mathrm{N}, 105.315^{\circ} \mathrm{W}$, UTM Zone 13 , $\mathrm{N}: 5,951,112.1, \mathrm{E}: 479,177.5$.

- $\quad$ SSA-YJP near the flux tower site, site id F8L6T, Lat/Long: $53.87581^{\circ} \mathrm{N}, 104.64529^{\circ} \mathrm{W}$, UTM Zone 13, N:5,969,762.5 E:523,320.2.

\subsubsection{Spatial Coverage Map}

Not applicable.

\subsubsection{Spatial Resolution}

These data are point measurements at the given locations.

\subsubsection{Projection}

Not applicable.

\subsubsection{Grid Description \\ Not applicable.}

\subsection{Temporal Characteristics}

\subsubsection{Temporal Coverage}

Samples were collected from the field every day from 0900 until 1300 local time. An independent data set was taken at each of the field campaigns in 1994. The specific dates for each collection of samples are given in the data table.

\subsubsection{Temporal Coverage Map}

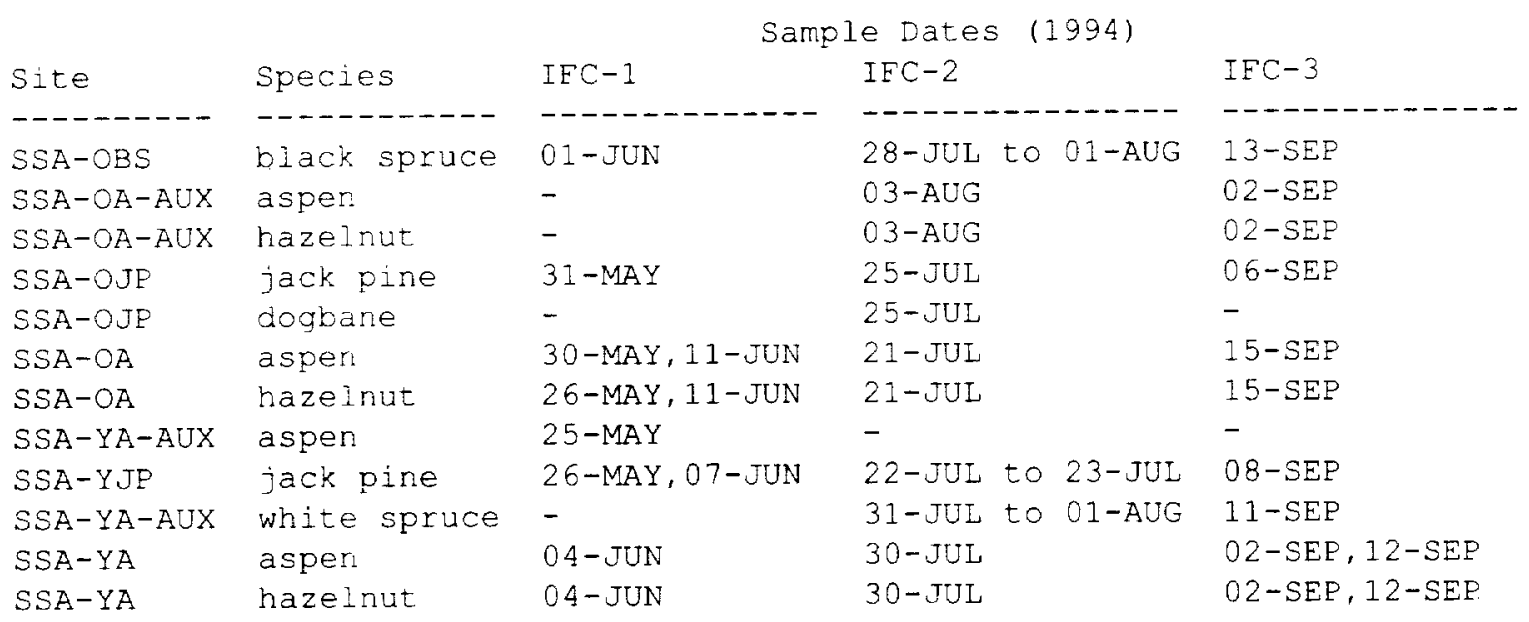

Page 8 


\begin{tabular}{|c|c|c|c|c|}
\hline Site & Species & Spring & $\begin{array}{l}\text { le Dates (1996) } \\
\text { Summer }\end{array}$ & Eall \\
\hline-------- & ------------ & ------------- & ---------------- & $--\cdots----------$ \\
\hline SSA-OBS & black spruce & 10-MAY & $14-J U L$ & $11-\mathrm{OCT}$ \\
\hline$S S A-O B S$ & black spruce & $19-J U N$ & - & - \\
\hline$S S A-O B S$ & black spruce & $21-J U N$ & - & - \\
\hline SSA-OBS & tamarack & - & $17-J U L$ & $10-\mathrm{OCT}$ \\
\hline SSA-OJP & jack pine & $18-J U N$ & $11-J U L$ & $13-\mathrm{OCT}$ \\
\hline SSA-OJP & jack pine & $23-J U N$ & - & - \\
\hline$S S A-O A-A U X$ & aspen & 24-JUN & $17-J U L$ & - \\
\hline$S S A-O A-A U X$ & hazelnut & $24-J U N$ & $17-J U L$ & - \\
\hline$S S A-Y J P$ & jack pine & 8-MAY TO 9-MAY & 12-JUL & $12-\mathrm{OCT}$ \\
\hline SSA-YJP & jack pine & $23-J U N$ & 15-JUL & - \\
\hline$S S A-Y A-A U X$ & white spruce & $8-M A Y$ & $10-J U L$ & $10-\mathrm{OCT}$ \\
\hline$S S A-Y A-A U X$ & white spruce & $20-J U N$ & - & - \\
\hline
\end{tabular}

\subsubsection{Temporal Resolution} Not applicable.

\subsection{Data Characteristics}

\subsubsection{Parameter/Variable}

The parameters contained in the data files on the CD-ROM are:

COIUmn Name
SITE_NAME
SUB_SITE
DATE_OBS
SEECIES
CANOPY_LOCATION
SAMPLE_GROWTH_YEAR
SAMPLE_ID
MEAN_EOLIAGE_HEMI_SURE_AREA_GY
ADAXIAL_MUNSELL_COLOR
ABAXIAL_MUNSELL_COLOR
NUM_TOTAL_NEEDLES
MEAN_LEAF_LENGTH
MEAN_LEAF_WIDTH
LEAE_LENGTH_TO_WIDTH_RATIO
MEAN_LEAE_THICKNESS
DARK_RESEIRATION
STOMATAL_LIMITATION
MAXIMUM_ASSIMILATION
TOTAL_FRESH_WEIGHT
FRESH_LEAF_WEIGHT
FRESH_LEAE_DENSITY
TOTAL_DRY_WEIGHT
DRY_LEAF_WEIGHT
DRY_WEIGHT_RATIO
DRY_LEAF_DENSITY
SHOOT_WATER_CONTENT
LEAE_WATER_CONTENT
CRTECN_CODE
REVISION_DATE




\subsubsection{Variable Description/Definition}

The descriptions of the parameters contained in the data files on the CD-ROM are:

\begin{tabular}{|c|c|}
\hline Column Name & Description \\
\hline SITE NAME & $\begin{array}{l}\text { The identifier assigned to the site by BOREAS, in } \\
\text { the format SSS-TTT-CCCCC, where SSS identifies } \\
\text { the portion of the study area: NSA, SSA, REG, } \\
\text { TRN, and TTT identifies the cover type for the } \\
\text { site, } 999 \text { if unknown, and CCCCC is the identifier } \\
\text { for site, exactly what it means will vary with } \\
\text { site type. }\end{array}$ \\
\hline SUB_SITE & $\begin{array}{l}\text { The identifier assigned to the sub-site by } \\
\text { BOREAS, in the format GGGGG-IIIII, where GGGGG is } \\
\text { the group associated with the sub-site } \\
\text { instrument, e.g. HYD06 or STAFE, and IIIII is the } \\
\text { identifier for sub-site, often this will refer to } \\
\text { an instrument. }\end{array}$ \\
\hline DATE_OBS & The date on which the data were collected. \\
\hline SPECIESS & $\begin{array}{l}\text { Botanical (Latin) name of the species (Genus } \\
\text { species). }\end{array}$ \\
\hline CANOPY_LOCATION & $\begin{array}{l}\text { Location in the canopy from which the sample was } \\
\text { taken. }\end{array}$ \\
\hline SAMPLE_GROWTH_YEAR & $\begin{array}{l}\text { The year in which the collected sample first } \\
\text { grew. }\end{array}$ \\
\hline SAMPLE_ID & The sample identifier used by data collectors \\
\hline MEAN_FOLIAGE_HEMI_SURE_AREA_GY & $\begin{array}{l}\text { The hemi-surface foliar area of the broadleaf } \\
\text { plus its petiole or of all the needles in the } \\
\text { needle growth year. }\end{array}$ \\
\hline ADAXIAL_MUNSELL_COLOR & Munsell color code of the adaxial surface. \\
\hline ABAXIAL_MUNSELL_COLOR & Munsell color code of the abaxial surface. \\
\hline NUM_TOTÄL_NEEDLES & The total number of needles on the shoot. \\
\hline MEAN_LEAF_LENGTH & $\begin{array}{l}\text { The mean lengths of three conifer needles within } \\
\text { the same growth year or of three measurements of } \\
\text { the same foliar broadleaf (the petiole is not } \\
\text { included). }\end{array}$ \\
\hline MEAN_LEAF_WIDTH & $\begin{array}{l}\text { The mean widths of three conifer needles witnin } \\
\text { the same growth year or of three measurements of } \\
\text { the same foliar broadleaf (the petiole is not } \\
\text { included). }\end{array}$ \\
\hline LEAF_LENGTH_TO_WIDTH_RATIO & $\begin{array}{l}\text { The ratio of the mean leaf length to the mean } \\
\text { leaf width. }\end{array}$ \\
\hline MEAN_LEAF_THICKNESS & $\begin{array}{l}\text { The mean thicknesses of three conifer needle: } \\
\text { within the same growth year or of three } \\
\text { measurements of the same foliar broadleaf (the } \\
\text { petiole is not included). }\end{array}$ \\
\hline DARK_RESPIRATION & $\begin{array}{l}\text { The lowest assimilation rate reached (negative) } \\
\text { by a foliar broadleaf or needle sample under } \\
\text { zero light illumination. }\end{array}$ \\
\hline STOMATAL_LIMITATION & $\begin{array}{l}\text { The limitation of photosynthesis by the stomates. } \\
\text { This is calculated using the maximum } \\
\text { photosynthesis reached under light saturating } \\
\text { conditions with and without stomatal influence. }\end{array}$ \\
\hline & The maximum assimilation reached by a plants \\
\hline
\end{tabular}




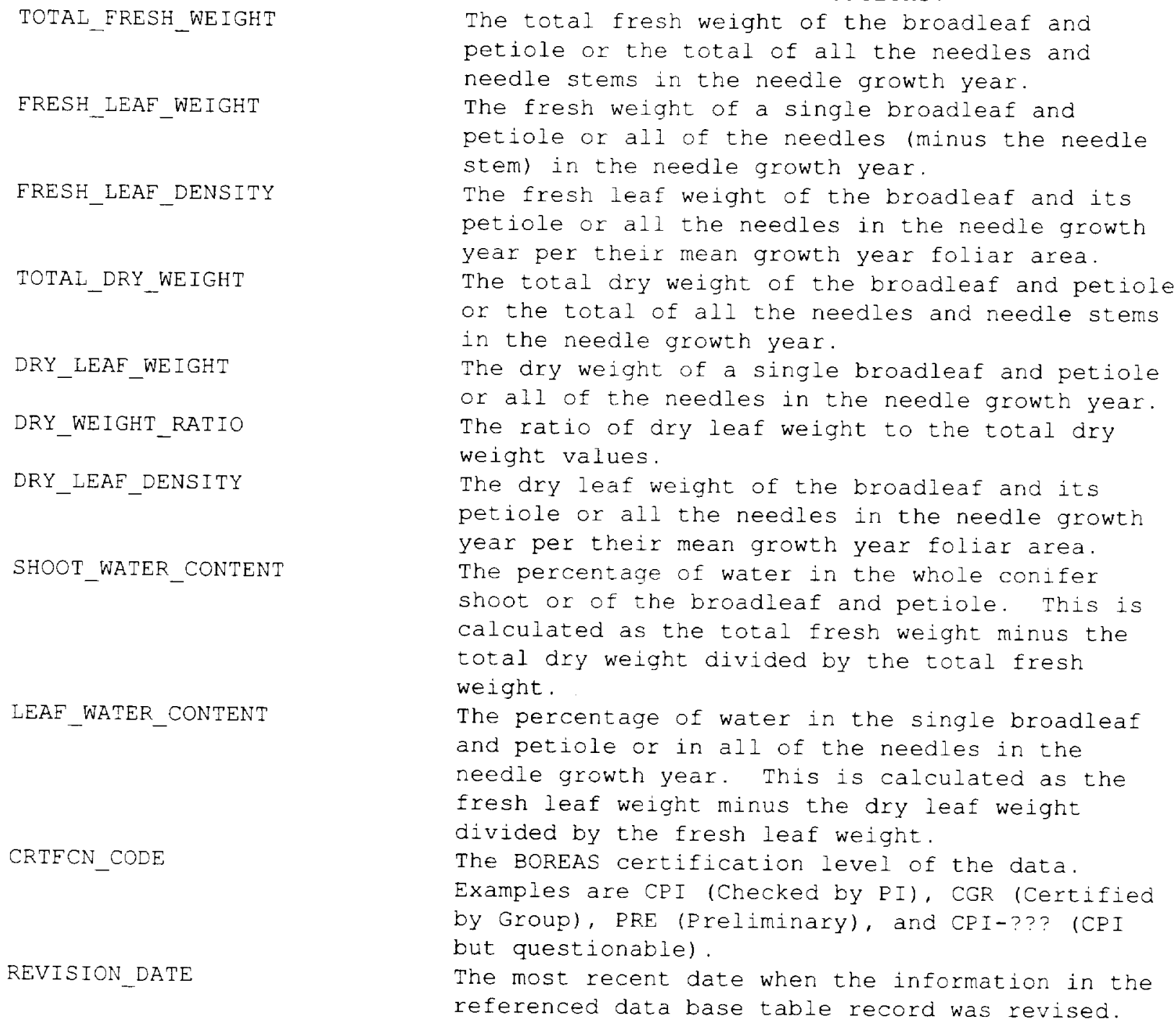

\subsubsection{Unit of Measurement}

The measurement units for the parameters contained in the data files on the CD-ROM are:

Column Name

SITE_NAME
SUB_SITE
DATE_OBS
SPECIES
CANOFY_LOCATION
SAMPLE_GROWTH_YEAR
SAMPLE_ID
MEAN_EOLIAGE_HEMI_SURF_AREA_GY
ADAXIAL_MUNSELL_COLOR
ABAXIAL_MUNSELL_COLOR
NUM_TOTAL_NEEDLES

Units

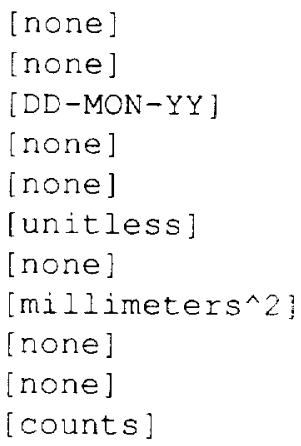

Page 11 


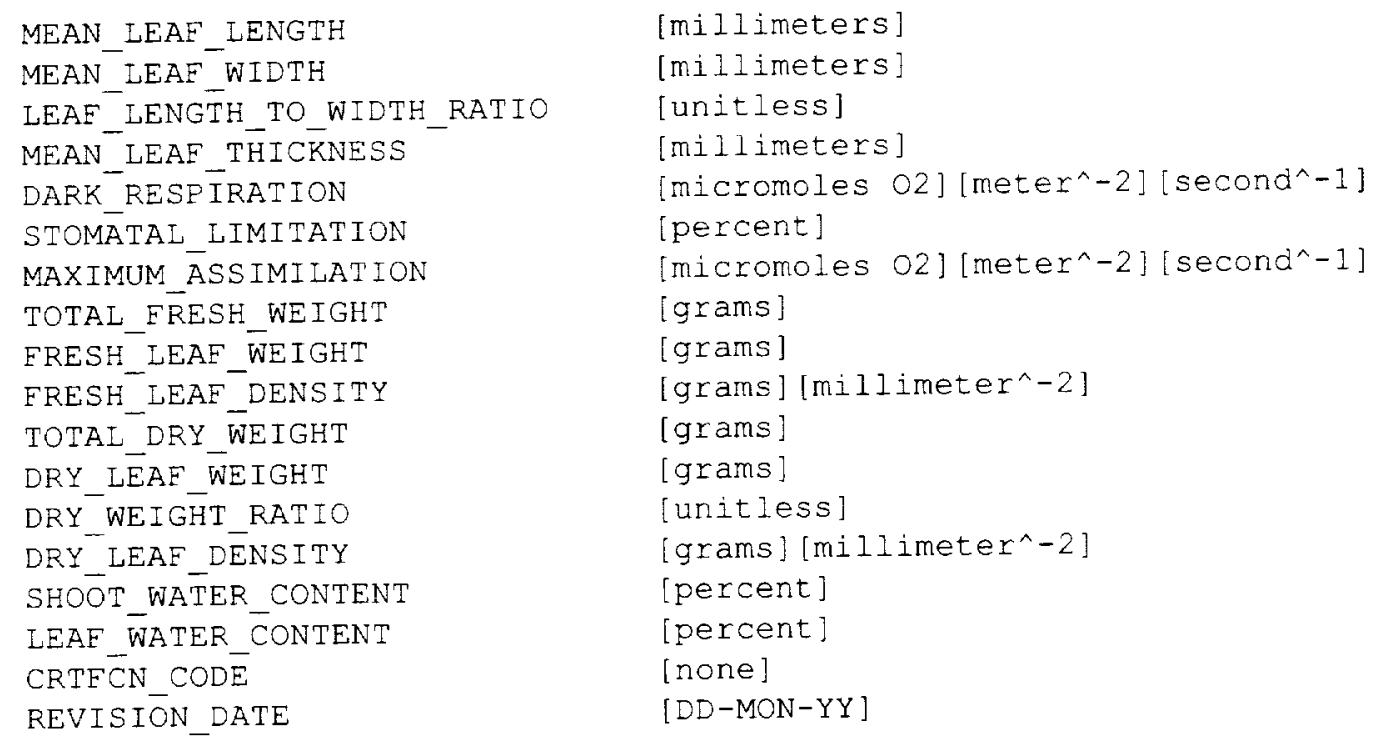

\subsubsection{Data Source}

The sources of the parameter values contained in the data files on the CD-ROM are:

\begin{tabular}{|c|c|}
\hline Column Name & Data source \\
\hline-------- & \\
\hline SITE_NAME & [BORIS Designation] \\
\hline SUB_SITE & [BORIS Designation] \\
\hline DATE_OBS & [Human Observer] \\
\hline SPECIEES & [Human Observer] \\
\hline CANOPY_LOCATION & [Human Observer] \\
\hline SAMPLE_GROWTH_YEAR & [Human Observer] \\
\hline SAMPLE_ID & [Human Observer] \\
\hline MEAN_FOLIAGE_HEMI_SURF_AREA_GY & [Laboratory Equipment] \\
\hline 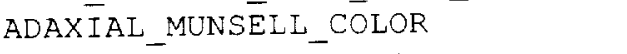 & [Human Observer] \\
\hline ABAXIAL_MUNSELL_COLOR & [Human Observer] \\
\hline NUM_TOTĀL_NEEDLES & [Human observer] \\
\hline MEAN_LEAF_LENGTH & [Laboratory Equipment] \\
\hline MEAN_LEAF_WIDTH & [Laboratory Equipment] \\
\hline LEAF_LENGT̄H_TO_WIDTH_RATIO & [Laboratory Equipment] \\
\hline MEAN_LEAF_TËICKNNESS & [Laboratory Equipment] \\
\hline DARK_RESP IRATION & [Laboratory Equipment] \\
\hline STOMATAL_LIMITATION & [Laboratory Equipment] \\
\hline MAXIMUM_ASSIMILATION & [Laboratory Equipment] \\
\hline TOTAI_FRESH_WEIGHT & [Laboratory Equipment] \\
\hline FRESH_LEAF_WEIGHT & [Laboratory Equipment] \\
\hline FRESH_LEAF_DENSITY & [Laboratory Equipment] \\
\hline TOTAL_DRY_WEIGHT & [Laboratory Equipment] \\
\hline DRY_LEAF_WEIGHT & [Laboratory Equipment] \\
\hline DRY_WEIGHT_RATIO & [Laboratory Equipment] \\
\hline DRY_LEAE_DENSITY & [Laboratory Equipment] \\
\hline SHOŌT_WATETE_CONTENT & [Laboratory Equipment] \\
\hline LEAF_WATER_CONTENT & [Laboratory Equipment] \\
\hline CRTF $\overline{C N}$ CODE & [BORIS Designation] \\
\hline REVISION DATE & [BORIS Designation] \\
\hline
\end{tabular}




\subsubsection{Data Range}

The following table gives information about the parameter values found in the data files on the CD-ROM.

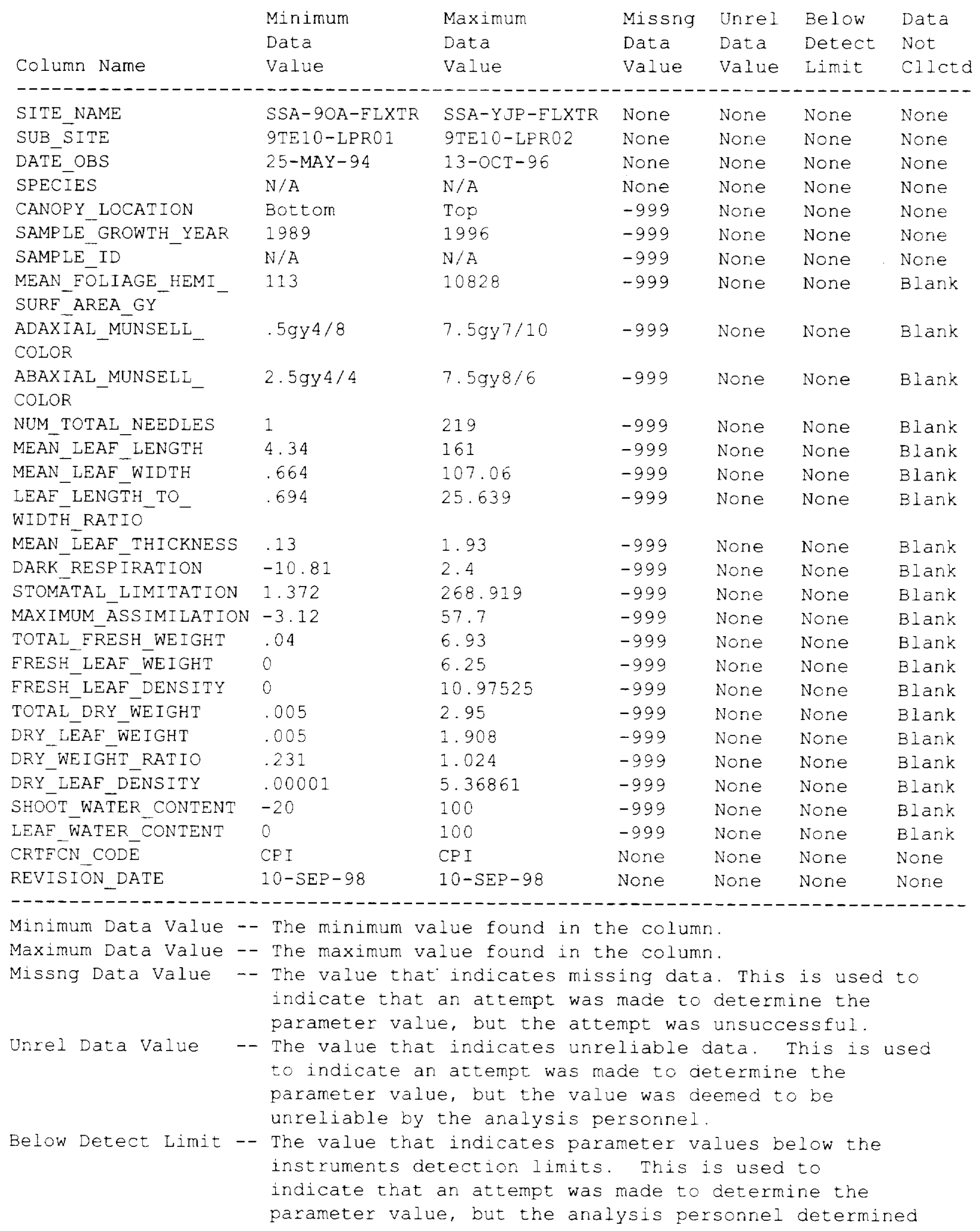

\section{Page 13}




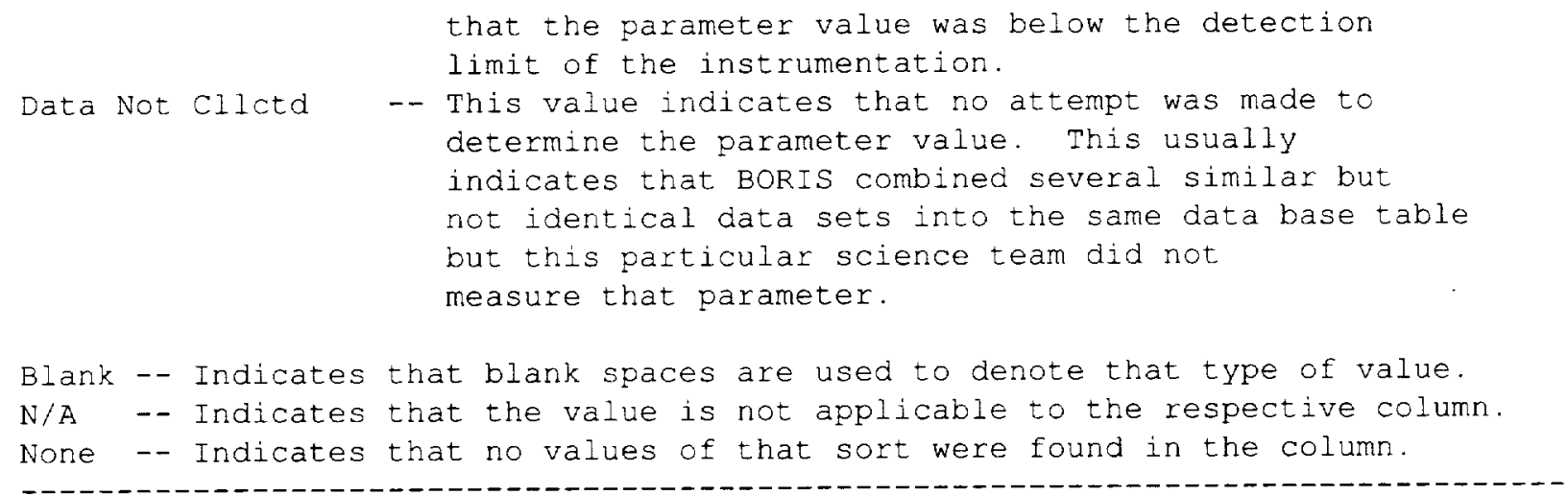

\subsection{Sample Data Record}

The following are wrapped versions of data record from a sample data file on the CD-ROM.

SITE_NAME, SUB_SITE,DATE_OBS, SPECIES, CANOPY_LOCATION, SAMPLE_GROWTH_YEAR, SAMPLE_ID, MEAN FOLIAGE HEMI SURF ÄREA GY, ADAXIAL_MUNSELL_COLOR, ABAXIĀL_MUNSELL_COLOR, NUM TOTAL_NEEDLES,MEAN_LEAF_LENGTH, MEAN_LEAF_WIDTH, LEAF_LENGTH_TO_WIDTH_RATIO, MEAN LEAF THICKNESS, DARK_RESPIRATION, STOMATAI_LIMITATION, MAXIMUM_ĀSSIMILATION, TOTAL FRES̄H WEIGHT, FRESH LEAF WEIGHT, FRESH LEĀE_DENSITY, TOTAL_DRY_WEIGHT, DRY_LEAF_WEĪGHT,DRY_WEIGHT_RATTIO,DRY_LEAF_DENSITY , SHOOT_WATER_CONTENT, LEA $\bar{F}$ WATER CONTENT, $\bar{C} R T E C N$ CODE, REVISION_DATE ' SSA-9OA-FEXTR', '9TE10-LPR01', 26-MAY-94,' Corylus cornuta', 'Top', '1994', '14', $285.0,{ }^{\prime} 2.59 y 6 / 10^{\prime}, ' 2.59 y 6 / 8^{\prime},-999.0,29.0,19.0,1.526,-999.0,-999.0,-999.0,-999.0$, $.05, .05,1.75439, .049, .049,-999.0,1.7193,2.0,2.0$, 'CPI', $10-S E P-98^{\prime}$ 'SSA-9OA-FLXTR', ' 9TE10-LPR01', 26-MAY-94, ' Corylus cornuta', 'TOP', '1994', '15', $263.0,{ }^{\prime} 2.5 \mathrm{gy} 6 / 10^{\prime},{ }^{\prime} 5 \mathrm{gy} 5 / 6^{\prime},-999.0,24.0,16.0,1.5,-999.0,-999.0,-999.0,-999.0,04$, $.04,1.52091, .01, .01,-999.0, .38023,75.0,75.0,{ }^{\prime} C^{\prime} I^{\prime}, 10-$ SEP-98

\section{Data Organization}

\subsection{Data Granularity}

The smallest unit of data tracked by the BOREAS Information System (BORIS) was the data collected at a given site on a given date.

\subsection{Data Format(s)}

The Compact Disk-Read Only Memory (CD-ROM) files contain American Standard Code for Information Interchange (ASCII) numerical and character fields of varying length separated by commas. The character fields are enclosed with single apostrophe marks. There are no spaces between the fields.

Each data file on the CD-ROM has four header lines of HyperText Markup Language (HTML) code at the top. When viewed with a Web browser, this code displays header information (data set title, location, date, acknowledgments, etc.) and a series of HTML links to associated data files and related data sets. Line 5 of each data file is a list of the column names, and line 6 and following lines contain the actual data. 


\section{Data Manipulations}

\subsection{Formulae}

stomlim $=\left[\left(a_{\max }-A\right) / a_{\max }\right] 100 \quad$ (Farquhar and Sharkey, 1982)

\subsubsection{Derivation Techniques and Algorithms}

None.

\subsection{Data Processing Sequence}

\subsubsection{Processing Steps}

Oxygen evolution measurements were recorded manually. Subsequent calculations were performed using Quattro Pro 6.0 for Windows 3.1.

\subsubsection{Processing Changes}

None.

\subsection{Calculations}

\subsubsection{Special Corrections/Adjustments}

None.

\subsubsection{Calculated Variables}

stomatal limitation $=[(\operatorname{amax}-\mathrm{A}) / \operatorname{amax}] 100($ Farquhar and Sharkey, 1982)

\subsection{Graphs and Plots}

None.

\section{Errors}

\subsection{Sources of Error}

Errors are primarily caused by variation in researchers' measurement techniques and in instrumentation. The data have received a quality review by TE-10 personnel, and all known sources of calculation errors have been corrected.

\subsection{Quality Assessment}

Data have received a quality review by TE- 10 personnel.

\subsubsection{Data Validation by Source}

Comparisons were made with other BOREAS results and with published results.

\subsubsection{Confidence Level/Accuracy Judgment}

None available, but it is felt that these data are accurate.

\subsubsection{Measurement Error for Parameters}

Not available.

\subsubsection{Additional Quality Assessments}

Calculated results were plotted and the plots were compared with those from published papers.

\subsubsection{Data Verification by Data Center}

Data were examined for general consistency and clarity. 


\section{Notes}

\subsection{Limitations of the Data}

None.

\subsection{Known Problems with the Data} None.

11.3 Usage Guidance

None.

\subsection{Other Relevant Information}

None.

\section{Application of the Data Set}

These data can be used for assessing photosynthetic differences between different species, age classes, and canopy layers in the boreal forest.

\section{Future Modifications and Plans}

None.

\section{Software}

\subsection{Software Description}

Calculations were performed using Quattro Pro 6.0 for Windows 3.1. This document was prepared using Microsoft Word 5.1 a for the Macintosh.

\subsection{Software Access}

None given.

\section{Data Access}

The photo response data are available from the Earth Observing System Data and Information System (EOSDIS) Oak Ridge National Laboratory (ORNL) Distributed Active Archive Center (DAAC).

\subsection{Contact Information}

For BOREAS data and documentation please contact:

ORNL DAAC User Services

Oak Ridge National Laboratory

P.O. Box 2008 MS-6407

Oak Ridge, TN 37831-6407

Phone: (423) 241-3952

Fax: (423) 574-4665

E-mail: ornldaac@ornl.gov or ornl@eos.nasa.gov 


\subsection{Data Center Identification}

Earth Observing System Data and Information System (EOSDIS) Oak Ridge National Laboratory (ORNL) Distributed Active Archive Center (DAAC) for Biogeochemical Dynamics

http://www-eosdis.ornl.gov/.

\subsection{Procedures for Obtaining Data}

Users may obtain data directly through the ORNL DAAC online search and order system [http://www-eosdis.ornl.gov/] and the anonymous FTP site [ftp://www-eosdis.ornl.gov/data/] or by contacting User Services by electronic mail, telephone, fax, letter, or personal visit using the contact information in Section 15.1.

\subsection{Data Center Status/Plans}

The ORNL DAAC is the primary source for BOREAS field measurement, image, GIS, and hardcopy data products. The BOREAS CD-ROM and data referenced or listed in inventories on the CD-ROM are available from the ORNL DAAC.

\section{Output Products and Availability}

16.1 Tape Products

None.

16.2 Film Products

None.

\subsection{Other Products}

These data are available on the BOREAS CD-ROM series.

\section{References}

\subsection{Platform/Sensor/Instrument/Data Processing Documentation}

LI-3100 LI-COR Area Meter Manual. Publication number 8805-0055, June 1988. LI-COR, Inc., 4421 Superior Street, P.O. Box 4425, Lincoln, NÈ 68504-0425.

\subsection{Journal Article and Study Reports}

Farquhar, G.D. and T.D. Sharkey. 1982. Stomatal conductance and photosynthesis. Annu. Rev. Plant Physiol. v33: 317-345.

Kharouk, V.I., E.M. Middleton, S.L. Spensor, B.N. Rock, and D.L. Williams. 1995. Aspen bark photosynthesis and its significance to remote sensing and carbon budget estimates in the boreal ecosystem. Water, Air and Soil Pollution. V82: 483-497.

Middleton, E.M., E.W. Chappelle, and A. DeLuca. 1995. Evaluating photosynthesis in boreal forest species with fluorescence measurements. IGARSS 1995.

Middleton, E.M., J.H. Sullivan, B.D. Bovard, A.J. DeLuca, S.S. Chan, and T.A. Cannon. 1997. Seasonal variability in foliar characteristics and physiology for boreal forest species at the five Saskatchewan tower sites during the 1994 Boreal Ecosystem-Atmosphere Study. Journal of Geophysical Research 102(D24):28,831-28,844.

Munsell Color (Firm). 1977. Munsell Color Charts for Plants Tissues. 2nd ed. Munsell Color (Firm), Baltimore, MD, 6 pp. 17 color charts. 
Newcomer, J., D. Landis, S. Conrad, S. Curd, K. Huemmrich, D. Knapp, A. Morrell, J. Nickeson, A. Papagno, D. Rinker, R. Strub, T. Twine, F. Hall, and P. Sellers, eds. 2000. Collected Data of The Boreal Ecosystem-Atmosphere Study. NASA. CD-ROM.

Sellers, P. and F. Hall. 1994. Boreal Ecosystem-Atmosphere Study: Experiment Plan. Version 1994-3.0, NASA BOREAS Report (EXPLAN 94).

Sellers, P. and F. Hall. 1996. Boreal Ecosystem-Atmosphere Study: Experiment Plan. Version 1996-2.0, NASA BOREAS Report (EXPLAN 96).

Sellers, P., F. Hall, and K.F. Huemmrich. 1996. Boreal Ecosystem-Atmosphere Study: 1994 Operations. NASA BOREAS Report (OPS DOC 94).

Sellers, P., F. Hall, and K.F. Huemmrich. 1997. Boreal Ecosystem-Atmosphere Study: 1996 Operations. NASA BOREAS Report (OPS DOC 96).

Sellers, P., F. Hall, H. Margolis, B. Kelly, D. Baldocchi, G. den Hartog, J. Cihlar, M.G. Ryan, B. Goodison, P. Crill, K.J. Ranson, D. Lettenmaier, and D.E. Wickland. 1995. The boreal ecosystem-atmosphere study (BOREAS): an overview and early results from the 1994 field year. Bulletin of the American Meteorological Society. 76(9):1549-1577.

Sellers, P.J., F.G. Hall, R.D. Kelly, A. Black, D. Baldocchi, J. Berry, M. Ryan, K.J. Ranson, P.M. Crill, D.P. Lettenmaier, H. Margolis, J. Cihlar, J. Newcomer, D. Fitzjarrald, P.G. Jarvis, S.T. Gower, D. Halliwell, D. Williams, B. Goodison, D.E. Wickland, and F.E. Guertin. 1997. BOREAS in 1997: Experiment Overview, Scientific Results and Future Directions. Journal of Geophysical Research 102(D24): 28,731-28,770.

Sullivan, J.H., B.D. Bovard, and E.M. Middleton. 1996. Variability in leaf-level $\mathrm{CO}_{2}$ and water fluxes in Pinus banksiana and Picea mariana in Saskatchewan. Tree Physiol. V17: 553-561.

\subsection{Archive/DBMS Usage Documentation}

None.

\section{Glossary of Terms}

A - The maximum assimilation reached by a plant's leaves/needles under light-saturating conditions and having stomatal limitations. This was measured in the field using an IRGA system.

$A_{\max }$ - The maximum assimilation reached by a plant's leaves/needles under light-saturating conditions and without stomatal limitations. This was measured in the laboratory using an oxygen electrode system.

Darkresp - The dark respiration by a plant's leaves/needles is the lowest assimilation rate reached (negative) under zero light illumination.

Stomatal limitation - The percent by which the stomates limit photosynthesis by a plant. 


\section{List of Acronyms}

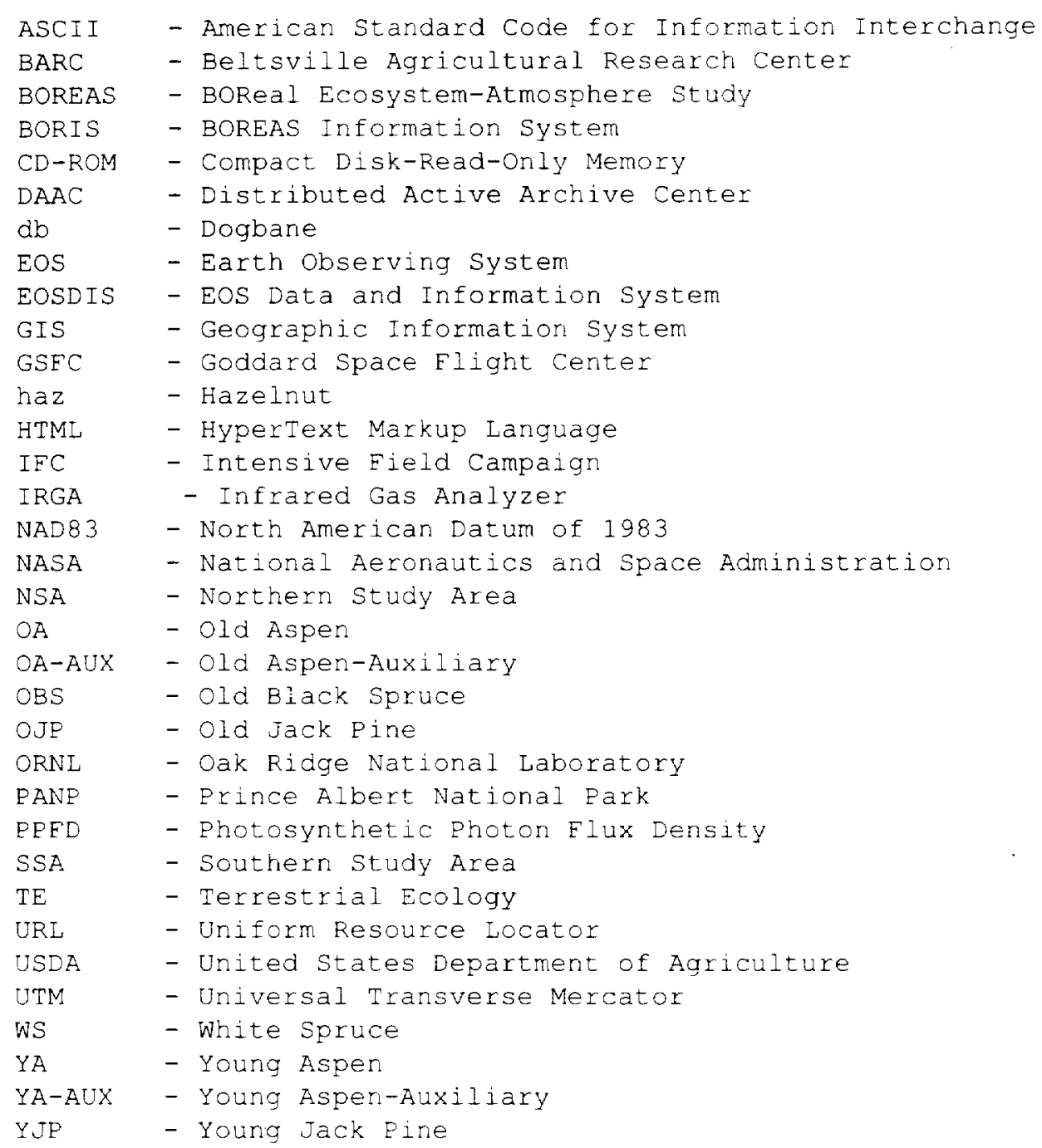

\section{Document Information}

\subsection{Revision Date}

Written: 21-Aug- 1997

Last Updated: 13-Aug-1999

\subsection{Document Review Date(s)}

BORIS Review: 14-Aug-1998

Science Review:

\subsection{Document ID}




\subsection{Citation}

When using these data, please include the following acknowledgment as well as citations of relevant papers in Section 17.2:

Middleton, E.M., of the Biospheric Sciences Branch, GSFC, NASA, and Sullivan, J.H., of the Department of Department of Natural Resource Sciences and Landscape Architecture, University of Maryland, College Park.

If using data from the BOREAS CD-ROM series, also reference the data as:

Middleton, E. and J. Sullivan, "CO 2 and Water Fluxes in the Boreal Forest Overstory:

Relationship to fAPAR and Vegetation Indices for Needles/Leaves." In Collected Data of The Boreal Ecosystem-Atmosphere Study. Eds. J. Newcomer, D. Landis, S. Conrad, S. Curd, K. Huemmrich, D. Knapp, A. Morrell, J. Nickeson, A. Papagno, D. Rinker, R. Strub, T. Twine, F. Hall, and P. Sellers. CD-ROM. NASA, 2000.

Also, cite the BOREAS CD-ROM set as:

Newcomer, J., D. Landis, S. Conrad, S. Curd, K. Huemmrich, D. Knapp, A. Morrell, J.

Nickeson, A. Papagno, D. Rinker, R. Strub, T. Twine, F. Hall, and P. Sellers, eds. Collected Data of The Boreal Ecosystem-Atmosphere Study. NASA. CD-ROM. NASA, 2000.

\subsection{Document Curator}

\subsection{Document URL}


Public reporting burden for this collection of information is estimated to average 1 hour per response, including the time for reviewing instructions, searching existing data sources, gathering and maintaining the data needed, and completing and reviewing the collection of information. Send comments regarding this burden estimate or any other aspect of this collection of information, including suggestions tor Davis Highway, Suite 1204, Arlington, VA 22202-4302, and to the Office of Management and Budget, Paperwork Reduction Project (0704-0188), Washington, DC 20503.

\begin{tabular}{l|l|l} 
1. AGENCY USE ONLY (Leave blank) & 2. REPORT DATE & 3. REPORT TYPE AND DATES COVERED
\end{tabular}

\begin{tabular}{l|l} 
October 2000 & Technical Memorandum
\end{tabular}

4. TITLE AND SUBTITLE

Technical Report Series on the Boreal Ecosystem-Atmosphere Study (BOREAS)

BOREAS TE-10 Photosynthetic Response Data

5. FUNDING NUMBERS

6. AUTHOR(S)

923

Elizabeth Middleton and Joseph Sullivan

RTOP: $923-462-33-01$

Forrest G. Hall and Andrea Papagno, Editors

7. PERFORMING ORGANIZATION NAME(S) AND ADDRESS (ES)

Goddard Space Flight Center

Greenbelt, Maryland 20771

8. PEFORMING ORGANIZATION REPORT NUMBER

$2000-03136-0$

9. SPONSORING / MONITORING AGENCY NAME(S) AND ADDRESS (ES)

10. SPONSORING / MONITORING AGENCY REPORT NUMBER

National Aeronautics and Space Administration

Washington, DC 20546-0001

TM-2000-209891

Vol. 163

\section{SUPPLEMENTARY NOTES}

J. Sullivan: University of Maryland, College Park;

A. Papagno: Raytheon ITSS, NASA Goddard Space Flight Center, Greenbelt, Maryland

12a. DISTRIBUTION / AVAILABILITY STATEMENT

12b. DISTRIBUTION CODE

Unclassified-Unlimited

Subject Category: 43

Report available from the NASA Center for AeroSpace Information,

7121 Standard Drive, Hanover, MD 21076-1320. (301) 621-0390.

13. ABSTAACT (Maximum 200 words)

The BOREAS TE-10 team collected several data sets in support of its efforts to characterize and interpret information on the gas exchange, reflectance, transmittance, chlorophyll content, carbon content, hydrogen content, nitrogen content, and photosynthetic response of boreal vegetation. This data set contains measurements of quantitative parameters and leaf photosynthetic response to increases in light conducted in the SSA during the growing seasons of 1994 and 1996 using an oxygen electrode system. Leaf photosynthetic responses were not collected in 1996 . The data are stored in tabular ASCII files.

14. SUBJECT TERMS

BOREAS, terrestrial ecology, boreal vegetation.

15. NUMBER OF PAGES 20

16. PRICE CODE

17. SECURITY CLASSIFICATION OF REPORT

Unclassified
18. SECURITY CLASSIFICATION OF THIS PAGE Unclassified
19. SECURITY CLASSIFICATION OF ABSTRACT

Unclassified
20. LIMITATION OF ABSTRACT

UL 